\title{
To Improve the Efficiency of Inspection Activities in Railway Industry
}

Jamilah Mohammad Sharif and Sabrinah Adam

To Link this Article: http://dx.doi.org/10.6007/IJARBSS/v12-i1/12089

DOI:10.6007/IJARBSS/v12-i1/12089

Received: 08 November 2021, Revised: 12 December 2021, Accepted: 24 December 2021

Published Online: 18 January 2022

In-Text Citation: (Sharif \& Adam, 2022)

To Cite this Article: Sharif, J. M., \& Adam, S. (2022). To Improve the Efficiency of Inspection Activities in Railway Industry. International Journal of Academic Research in Business and Social Sciences, 12(1), 773 - 778.

Copyright: (c) 2022 The Author(s)

Published by Human Resource Management Academic Research Society (www.hrmars.com)

This article is published under the Creative Commons Attribution (CC BY 4.0) license. Anyone may reproduce, distribute, translate and create derivative works of this article (for both commercial and non0-commercial purposes), subject to full attribution to the original publication and authors. The full terms of this license may be seen at: http://creativecommons.org/licences/by/4.0/legalcode

Vol. 12, No. 1, 2022, Pg. $773-778$

Full Terms \& Conditions of access and use can be found at http://hrmars.com/index.php/pages/detail/publication-ethics 


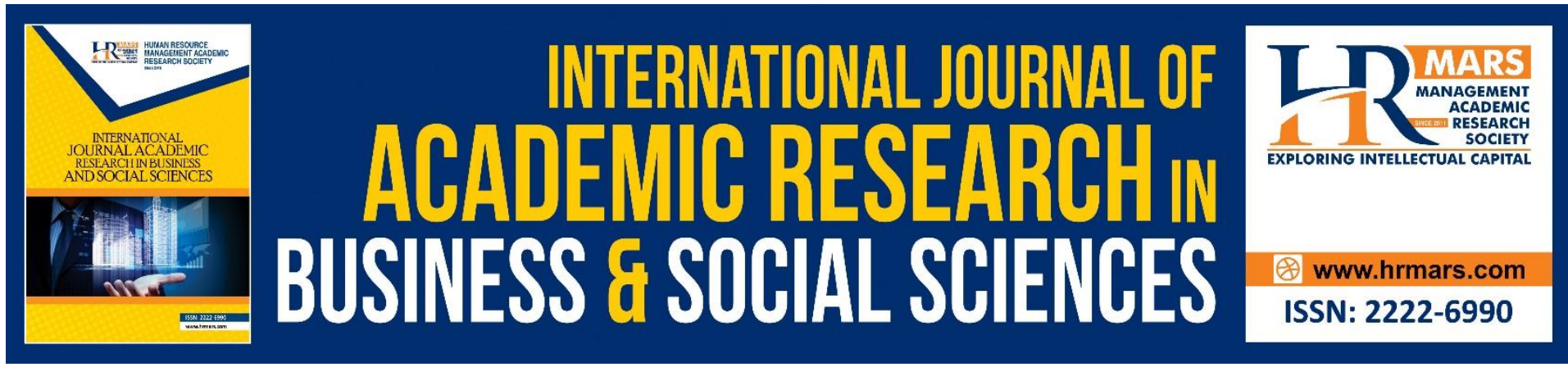

\title{
To Improve the Efficiency of Inspection Activities in Railway Industry
}

\author{
Jamilah Mohammad Sharif and Sabrinah Adam \\ Azman Hashim International Business School, Universiti Teknologi Malaysia (UTM), Malaysia \\ Email: jamilah83@graduate.utm.my
}

\begin{abstract}
The purposed of this research is to proposed the standard operating procedure (SOP) on the inspection activities performed in railway industry. Action research was applied in this study and proposed SOP was tabled to improve the inspection activities. Qualitative and quantitative data were used to gather data for this research. The qualitative data was collected during the interview with 3 employees of the railway company. In addition, the quantitative data consist of survey was have been collected for research purposes with the 12 participants. The theory of goal setting performance management system will be used to further analyse the information collected (Locke, 2006). The effectiveness of the intervention will be evaluated once the proposed intervention has been implemented. The expected outcome is an increase in the number of inspections and the effectiveness of inspection activities to enhance railway asset performance. Hence, the same SOP can be adopted by other railway company in improving the services.
\end{abstract}

Keywords: Employee Performance during the Covid-19 Pandemic, Standard Operating Procedure, Job Satisfaction, Motivation, Work Schedule

\section{Introduction}

Without appropriate asset maintenance, services run high risks of failure with knock-on effects for user satisfaction and asset professionals' performance (Markeset and Kumar, 2003). The purpose of the inspection is to identify any degraded asset that can lead to a major failure, such as a derailment. Inspection activities will help the operator to plan the predictive maintenance that can safe life and cost effective. The SOP is important to ensure the employee can produce reliable result, improve efficiency, standardize the process flow and reduce time in performing the inspection activities.

The company was created in September 2011 and in October 2011, the company acquired ownership of the Klang Valley railway project from Prasarana Malaysia Berhad (PMB). The responsibilities of the company are overseeing and monitoring the construction of all Klang Valley Project including elevated structures, stations and depots. In addition, the company is responsible to manage the underground works consist of tunnelling and construction of underground stations. 
The company is working closely with others agencies to develop the project. The MMC-Gamuda Sdn Bhd is the Project Delivery Partner (PDP) and Agensi Pengangkutan Awam Darat (APAD) is the supervising agency for the project.

The Asset and Facilities Management Department (AFMD) is one of department in the company that responsible to ensure the asset was maintain and operate according to the original equipment manufacturer (OEM) and best practice by the operator. AFMD had conducted several activities to ensure the full performance of the railway assets. One of the main activities was weekly inspections to monitor asset conditions to ensure the functionality of assets. This study focused on increasing the effectiveness and efficiency on inspection activities by implementing the SOP.

\section{Literature Review}

\section{Railway Industry in Malaysia}

The railway industry is important because it can shorten travel times and be cost-effective. On 21 December 2021, Transportation Minister Datuk Seri Dr Wee Ka Siong launched the new Rapid KL My50 unlimited travel pass. The pass costs RM50 monthly with unlimited travel along the LRT, MRT, Monorail, BRT, Rapid KL bus and MRT feeder bus in the Klang Valley. This could benefit about 800,000 daily commuters in the Klang Valley. However, after being affected by the COVID-19 pandemic, commuters are averaging 500,000 per day. This show, it is crucial for the railway operator and asset owner to ensure the safety of commuters and the reliability of the service.

The previous study emphasizes on how to increase the efficiency and effectiveness in performing the inspections activities. The possible solution is rescheduling the inspection based on a framework developed by Viera (Vieira et al., 2004). The framework provides requirements to mitigate disruption risks on a predetermined schedule in a realistic way (Osman, 2018). The study conducted by Khan, has proposed a systematic Maximum Credible Accident Scenario (MCAS) procedure for assessing failure scenarios (accidents) within a process system (Khan, 2003). Standard operating procedure (SOP) not only applicable and relevant to complex businesses it also covers the minor aspects of work (Ethiop, 2012). Thus, this inspection activities required SOP in order to guide employee to performed their task at their best level.

\section{The Impact of Pandemic COVID-19}

AFMD was responsible to performed the inspection by weekly basis. The AFMD was formed in 2016 with six employees and in 2021 the AFMD increased to 12 employees. The 12 employees are required to perform a weekly inspection according to their unit and specialities. Periodic inspection is also part of the criteria of employees Key Performance Index (KPI), they need to perform 4 inspections weekly.

The weekly inspection report will be shared with the operator to allow them to take further action on the inspection's findings. However, in early 2021, the AFMD fails to carry out 4 inspections weekly. Failure to achieve the KPIs may result in the lack of monitoring of the asset. The asset may expose to unpredicted failure and may reduce the mean time before failure (MTBF) life span. As the result of the weekly inspection, AFMD will highlight equipment or facilities that need to be replace or repair by the operator. 
The movement control order (MCO) had limited the inspection activities. Since 18 March 2020, AFMD had struggling in managing the manpower during the MCO. AFMD is allowed to continue the operation however there are several limitations in performing inspection at stations and depots. Staff need to get approval from head of department and head of Standard and Compliance department. In addition, staff also need to do swab test before performed the inspection activities.

Based on interview with the head of department, AFMD should performed 350 inspections per year, however for the year 2021 they did not perform any inspection from January to March and they only manage to performed 113 inspections for year 2020. Besides the impact of $\mathrm{MCO}$, there is several others caused that led to this problem such as lack of manpower and skilled staff and no standard operating procedure (SOP). One of the impacts of not having a SOP the report submitted to Head of Department (HOD) are not standardize.

New goals or schedule can be set by considering the limitation and current performance of the staff and the department depending on the circumstances facing by AFMD. The theory of goals setting made by Edwin Locke stated that when the goal setting is reliable and relevant to the current environment, employees or organizations are capable of performing better (Locke, 2006).

\section{Research Methodology}

The objective of this research is to improve the effectiveness and efficiency of inspection activities by introducing new standard operating procedure (SOP) to the employees. The qualitative data collected by interviewing respondent to gather information related to inspection schedule, time management, standard operating procedures, technology required to improve inspection activities and other relevant activities. The data collected by interviewing the HOD and three other staff from AFMD. Data will also have been collected during the researcher's observations when dealing with the respondent. The objective of the interview is to identify the problems that led to low efficiency of inspections activities and the possible suggestion to improve the performance.

The researcher shall obtain the data from 5 Likert scale rating. Likert scale was devised in order to measure 'attitude' in a scientifically accepted and validated manner (Likert, 1932). The Likert scale used in this study because the questions is easy, respondent may interest to participate and it will create appropriate data sample. The survey is made using google forms and distributed via digital platforms. These questionnaires had divided into 3 sections. Section A covers on the employee satisfaction, Section B covers on inspector performance and Section $\mathrm{C}$ on the demography in increasing the efficiency of inspection activities.

\section{Data Analysis}

The data that has been obtained during the survey questionnaires will be analyse using the SPSS software version 25 . The data analysis of the study consists of descriptive analysis which will analyse the frequency, mean, median, standard deviation and variance in the study. For the quantitative data, the data will be analyse using Wilcoxon Test to compare the data before and after the intervention. In addition, the Miles and Huberman (2014) technique will be use to transcribe the interview answer gathered during the interview sessions. Both, qualitative and quantitative data will used to identify the effectiveness of the intervention. 


\section{Developing Standard Operating Procedure (SOP)}

The organisation or company that need to be certified by SIRIM shall pass the audit surveillance. The audit will access on several aspect including the SOP of the company. The benefit of certification is including the company may improve on internal processes, increase customer satisfaction, better defined processes and sub-processes and most important is the company will identify opportunities for improvement. Good performance must be achieved through the establishment and management of robust quality systems with their integrated quality documents, including standard operating procedures (Manghani, 2011).

The SOP is the important document in every task performed by the employee. The main objective of developing the SOP is to ensure all employee perform the work correctly and in the same manner. A SOP should be available at the location where the work is being conducted. SOPs facilitate an ongoing application of processes and procedures. Therefore, even when there are changes in personnel, organizations able to avoid inconsistencies and safety risks (Frank, 2010).

\section{Conclusion}

The standard operating procedure has been implemented to AFMD. The implementation of the SOP has increased productivity and promote knowledge transfer that leading to the reduction of errors and improvement of organizational efficiency. This to ensure the railway is operating safely as designed and directly able to increase the reliability of the railway asset and reducing the risk of hazards and failures. The Malaysia railway industry is far behind other developed countries in Asia such as Hong Kong, Japan and Korea. Thus, this study should help to increase the performance of rail service in Malaysia by providing passengers with a safe, reliable, on-time and comfortable journey. In addition, the railway operator will save money, time and resources when the effective SOPs has been implemented in their organization. Apart from the rail industry, the academic industry could also benefit from this study.

\section{References}

Grassie, S., Nilsson, P., Bjurstrom, K., Frick, A., Hansson, L. G. (2002). Alleviation of rolling contact fatigue on Sweden's heavy haul railway Wear, Vol. 253, pp. 42-53

Usup Riassy Christa, Vivy Kristinae. (2021). The effect of product innovation on business performance during COVID 19 pandemic. Journal of Science Direct.

Tamer, M., Alkadash, F. A. (2020). An Integrative Conceptual Framework On Employee Performance During Covid-19 Pandemic For Bahrain SMES. Journal of Science Direct.

Faisal, I. K., Haddara, M. M. (2003). Risk-based maintenance (RBM): a quantitative approach for maintenance/inspection scheduling and planning. Faculty of Engineering and Applied Science, Memorial University of Newfoundland, St. John's, Nfld, Canada A1B 3X5. Retrieved from the Infona Portal:http//www.infona.pl/resource/ bwmeta1.element.elsevier-97a60346-072c-3280-b18dcaec31db561b

Osman, B., Haniff, M., Kaewunruen, S. (2018). Value of rail inspection reschedule Journal of Sagepub.

Osman, B., Haniff, M., Kaewunruen, S., Jack, A. (2017). Optimisation of schedules for the inspection of railway tracks. Retrieved from research Birmingham: https://research.birmingham.ac.uk/portal/en/publications/optimisation-of-schedules for-the-inspection-of-railway-tracks

Edwin, A. L. (2006). New Directions in Goal-Setting Theory. Journal of Sagepub. 
Markeset, T., Kumar, U. (2003). Design and development of product support andmaintenance concepts for industrial systems. Retrieved from emerald.com:

Ethiop, J. (2012). Reviewing the Values of a Standard Operating Procedure. Journal of Ethiopian Journal of Health Science.

Miles and Huberman. (2014). Qualitative Data Analysis: A Methods Sourcebook and The Coding Manual for Qualitative Researchers. Retrieved from Taylor \& Francis Online https://www.tandfonline.com/doi/abs/10.1080/10572252.2015.975966?journalCode $=$ tcq20

Manghani, K. (2011). Quality assurance: Importance of systems and standard operating procedures. Retrieved from picroline:

https://www.picronline.org/article.asp?issn=22293485; year=2011; volume=2; issue=1;s page $=34$; epage $=37$; aulast $=$ Manghani 